\title{
MECHANISMS CONTROLLING THE PRODUCTION AND TRANSPORT OF METHANE, CARBON DIOXIDE, AND DISSOLVED SOLUTES WITHIN A BOREAL PEATLAND
}

\author{
Progress Report
}

$\mathrm{DOE} / \mathrm{ER} / 61013--2$

\author{
For Period January 15, 1991 to July 14, 1992
}

DE92 011752

\author{
D.I. Siegel \\ Syracuse University
}

Syracuse, New York 13244-1070

April 9, 1992

Prepared For

THE U.S. DEPARTMENT OF ENERGY
AGREEMENT NO. DE-FG02-90ER61013

\section{DISCLAIMER}

\begin{abstract}
This report was prepared as an account of work sponsored by an agency of the United States Government. Neither the United States Government nor any agency thereof, nor any of their employees, makes any warranty, express or implied, or assumes any legal liability or responsibility for the accuracy, completeness, or usefulness of any information, apparatus, product, or process disclosed, or represents that its use would not infringe privately owned rights. Reference herein to any specific commercial product, process, or service by trade name, trademark, manufacturer, or otherwise does not necessarily constitute or imply its endorsement, recommendation, or favoring by the United States Government or any agency thereof. The views and opinions of authors expressed herein do not necessarily state or reflect those of the United States Government or any agency thereof.
\end{abstract}




\section{INTRODUCTION}

Peatlands are one of the most important terrestrial reservoirs in the global cycie for carbon, and are a major source for atmospheric methane (Harriss et. al.; Sebacher et. al, 1986). However, little is known about the dynamics of these carbon reservoirs or their feedback mechanisms with the pool of atmospheric $\mathrm{CO} 2$ during the Holocene. Specifically, it is unknown whether large peat basins are sources, sinks, or steady-state reservoirs for the global carbon cycle. In particular, the production and transport of methane, carbon dioxide, and dissolved organic carbon form the deeper portions of these peatlands is unknown.

Our DOE research program is to conduct an integrated ecologic and hydrogeochemical study of the Glacial Lake Agassiz peatlands (northern Minnesota) to better understand the carbon dynamics in globally significant peat basins. Specifically, our study will provide local and regional data on 1). rates of carbon accumulation and loss and fluxes of methane in the peat profiles, 2 ). the physical and botanical factors controlling the production of methane and carbon dioxide in the wetland, and 3). the role of hydrogeologic processes in controlling the fluxes of gases and solutes through the peat. We intend to use computer simulation models, calibrated to field data, to scaleup from local to regional estimates of methane and carbon dioxide within the basin. How gases and dissolved organic carbon escapes from peatlands is unknown. Clymo (1984) suggests that the concentrations of methane produced in the upper peit are sufficient to produce diffusion gradients towards the surface. Alternatively, gas may move through the peat profile by groundwater advection (Siegel and Glasser, 1987; Siegel, 1984).

Peatland vegetation landforms are related to the peatland hydrology. About half of the large northern wetlands consist of reed-sedge dominated vegetation (fens) having surface water chemistry of groundwater in the mineral soils underlying the peat. In contrast, about one third of the wetlands consist of raised bogs, mosses and trees tolerant to the acidic and very dilute surface water. Raised bogs theoretically are recharge areas where water moves vertically downward to 
replenish local groundwater flow systems (Siegel, 1984). In contrast, fens are places where groundwater discharges to the land surface.

\section{RESEARCH PROGRAM}

The research program involves an integrated hydrogeologic, ecological, and geochemical study of the Glacia! Lake Agassiz peatlands, northern Minnesota, one of the largest mires in North America. The research protocol basically involves the collection of detailed vertical profiles of; 1) pore water chemical composition, 2) methane and carbon dioxide concentrations, 3) vegetation stratigraphy, and ) hydraulic measurements including hydraulic head and hydraulic conductivity. These data will be integrated with computer simulation models of solute and gas transport, interactive volume averaging models, and isotopic characterization of carbon in gas and dissolved solutes to determine the flux rates of $\mathrm{CH} 4$ through the peat column and carbon storage in the peat mass (see original proposal for details).

In the summer 1990 (the first field season), we collected data from 33 profiles covering every major bog-fen complex in the greater Glacial Lake Agassiz peatland. The sites were approximately divided between fens and bogs to characterize the methane fluxes associated with different vegetation communities (Fig. 1). The results of that season, reported in a DOE Research Summary (Siegel and Glaser, 1991) were extraordinarily provocative, and resulted in modifications of our second field season in summer 1991. Initially we proposed that field studies in 1991 would characterize temporal changes (on seasonal basis) in methane flux and soil temperatures. However, the hydraulic heads and methane concentrations in the peat obtained during drought summer 1991 were radically different from that repoited in the literature. First, ground water moved upward and discharged to the land surface at all bogs, instead of moving downwards according to previous work. Water even flowed freely from piezometers installed only 1 meter into the peat. Second, methane saturation was ubiquitous throughout peat columns, and 
overpressured at places in the bog by as much as 2 atmospheres. Methane and pore water expelled as much as 2 meters above the land surface when the pressure was released when the piezometers were removed from the peat. Previously, it had been thought that most methane is mostly formed within the upper $50 \mathrm{~cm}$ of the peat column, not at depth. Preliminary isotopic measurements of carbon in methane from the first field season suggested that methanogenic bacteria at depth may obtain their carbon from the ground water discharging upward into the peat column.

\section{RESULTS FROM JANUARY 15, 1991 TO JULY 14, 1992}

The 1990 field season was redesigned to address why the extraordinarily high methane concentrations of methane occurred in the peatland, and why the groundwater hydraulics was reversed from that observed during the previous field season. We revisited about two thirds of the sites sampled to recollect hydraulic measurements, pore water chemical data, and methane. Dr. Jeff Chanton (Florida State University) and Dr. Alan Lazarus (NCAR) collaborated at no charge to obtain a suite of additional isotopic data on $\mathrm{CH}_{4}$ and $\mathrm{CO} 2$ and surface flux measurements from chambers. These methane llux measurements will be compared to fluxes calculated from the methane profiles to evaluate the effectiveness of our measurements in "scaling-up" to the larger peatland.

Again, the natural system produced results that were surprising. Between summer 1990 and summer 1991, the 10-year drought effectively broke and the upper meter of peat was resaturated. In contrast to 1990 , dissolved methane in 1991 was mostly undersaturated and methane profiles had a structure and appearance similar to that predicted by diffusion or hydrodynamic dispersion (Fig. 2). Furthermore, head measurements showed that ground water in 1991 moved downward under the bogs, as predicted by previous theory. Basically, there was a 
complete reversal of groundwater hydrodynamics, from summer 1990 to summer 1991, accompanied by a rapid and large loss of methane from the peat column.

These findings will be presented at the Spring American Geophysical Union Meeting in 1992 (Montreal) and INTECOL IV International Wetlands Conference in Columbus, Ohio. Draft papers on the changes in methane values in the peatland have been written and will be shortly submitted to Geology and the Journal of Ecology. Experiments are in progress to determine values for solute diffusion coefficients and dispersivity in peat. Samples of peat pore water have been sent for analysis of oxygen and hydrogen isotopes to characterize the effective "long-term" or steady-state hydrogeologic setting of the major bog-fen complexes. Analyses of pore water chemistry and isotopes of carbon and hydrogen in methane are still in progress.

FUTURE STUDY JULY 15, 1992 - JULY 14, 1993

The remainder of the project will be dedicated to data interpretacion and report writing. The amount of research still to be done is very large because of the unusual and significant findings of the project. To this end, I have requested supplemental funding from DOE for additional graduate student support. For the remainder of the project the following will be done:

1). Computer simulation studies, using information from geophysical and sedimentological studies, will be done to determine why drought causes the recharge-discharge function of bogs to completely reverse. The sedimentological studies, to be done by Mr. Mike Stone (a senior geology student), will determine if the bogs are underlain by coarser, more permeable sediments than the fens. Scismic studies (in collaboration with Dr. George Shaw, Union College) in March 1992 will attempt to determine the extent 10 which sand and gravel connection beach ridges with the peatlands. 
2). Experiments on the diffusion and dispersion of solutes in peat will be continued by Mr. Dan Ours, a M.S. Hydrogeology Student). These data will be integrated in the methane solute transport models to be done by Mr. Edwin Romanowicz (PhD. student, Hydrogeology).

3). Isotopic data on water will be used with solute profiles in peat pore water and the peat itself to characterize the extent to which bogs and fens are long-term recharge or discharge zones. The metal stratigraphy of the peat cores is being done by Mr. Pat Korths and Ms. Nan Rutkowski, both M.S. students in Hydrogeology.

4). Evaluation of the origin of the methane in the peat columns will be made by the Pl in collaboration with Dr. Alan Lazarus (NCAR) and Dr. Jeff Chanton (Florida State University). Chanton and Lazarus's flux rates from chamber experiments will be compared to flux rates calculated from methane profiles and diffusion-advection modeling.

5). The quantity of methane in the peat in 1990 and 1991 will be determined using interactive volume averaging modeling (IVM) by Ms. Yiping Shen, a M.S. Hydrogeology graduate student.

6). Synthesis of all the data to determine the differences in the flux rates from the peatlands during drought and wet times will be directed by the PI, and involve all members of the project team. We expect numerous publications in many formats to come out of this project.

Details and references to staffing (including VITA), our approach, facilities, and methodologies are found in original proposal. 


\section{REFERENCES CITED}

Clymo, R.S., 1984, The limits of peat growth. Philosophical Transactions of the Royal Society of London B303: 605-654.

Harriss, R.C. and others, 1987, Methane flux from northern peatlands, Nature, 315:652-653.

Siegel, D.I., 1984, Ground water and the evolution of patterned mires, Glacial Lake Agassiz Peatlands, northern Minnesota, Journal Ecology, 75:743-754.

Siegel, D.I. and Glaser, P.H., 1987, Ground water flow in a bog-fen complex, Lost River peatland, northern Minnesota, Journal of Ecology, 75:743-754.

Siegel, D.I. and Glaser, P.H., 1991, Mechanisms controlling the production and transport of methane, carbon dioxide, and dissolved solutes within a large boreal peatland basin, Department of Energy Research Summary, No. 11, June 1991, 4pp. 


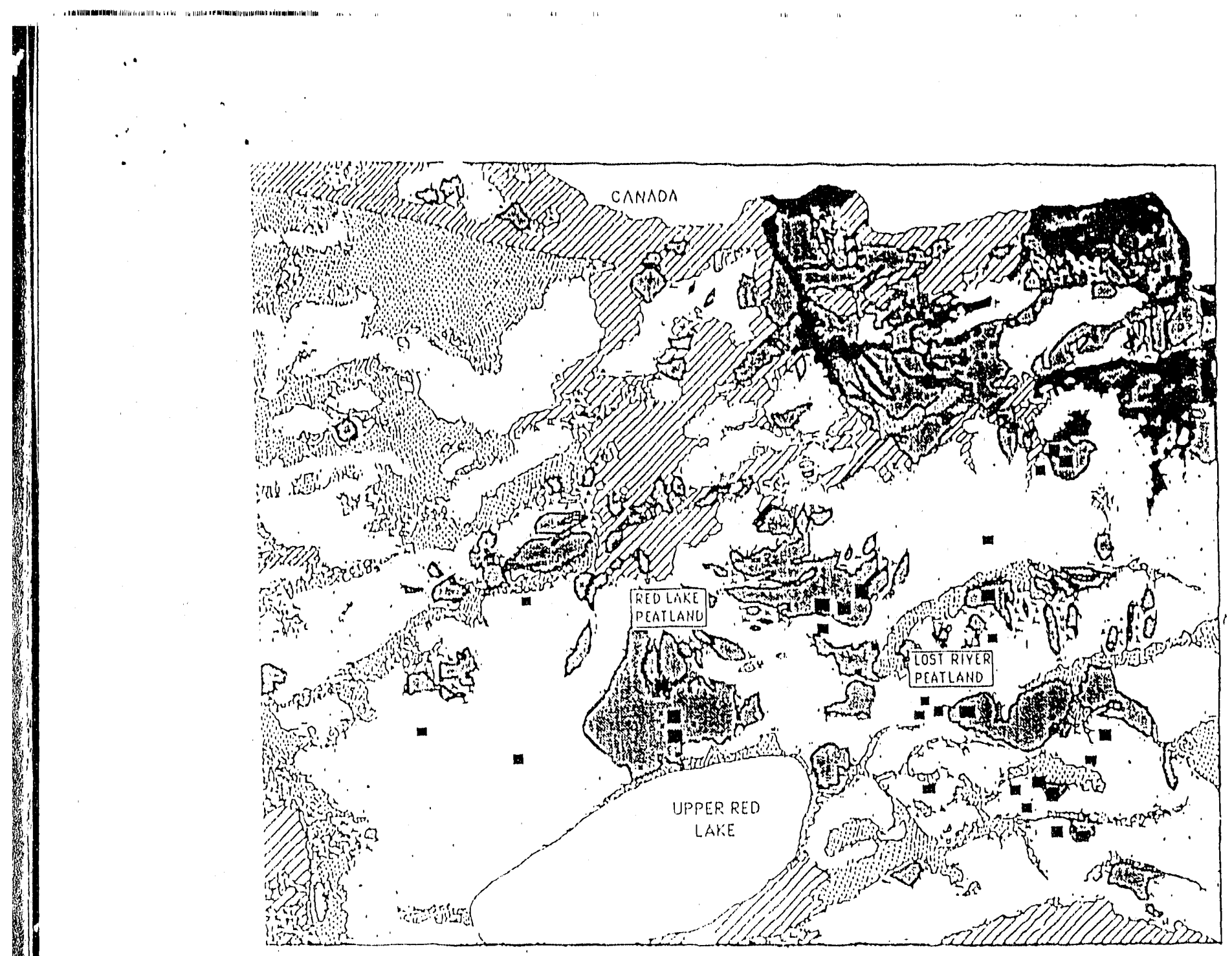

rigure 1. Iocation map showing sities for peat cores and profiles of peat pore water chemistry and hydraulic head. Sites are solid squares. rrey areas are raised bogs. White areas are fens. Stippled and slasned areas are where mineral soil crops at the land surface. Black areas are where lake clays occur at tine land surface. 


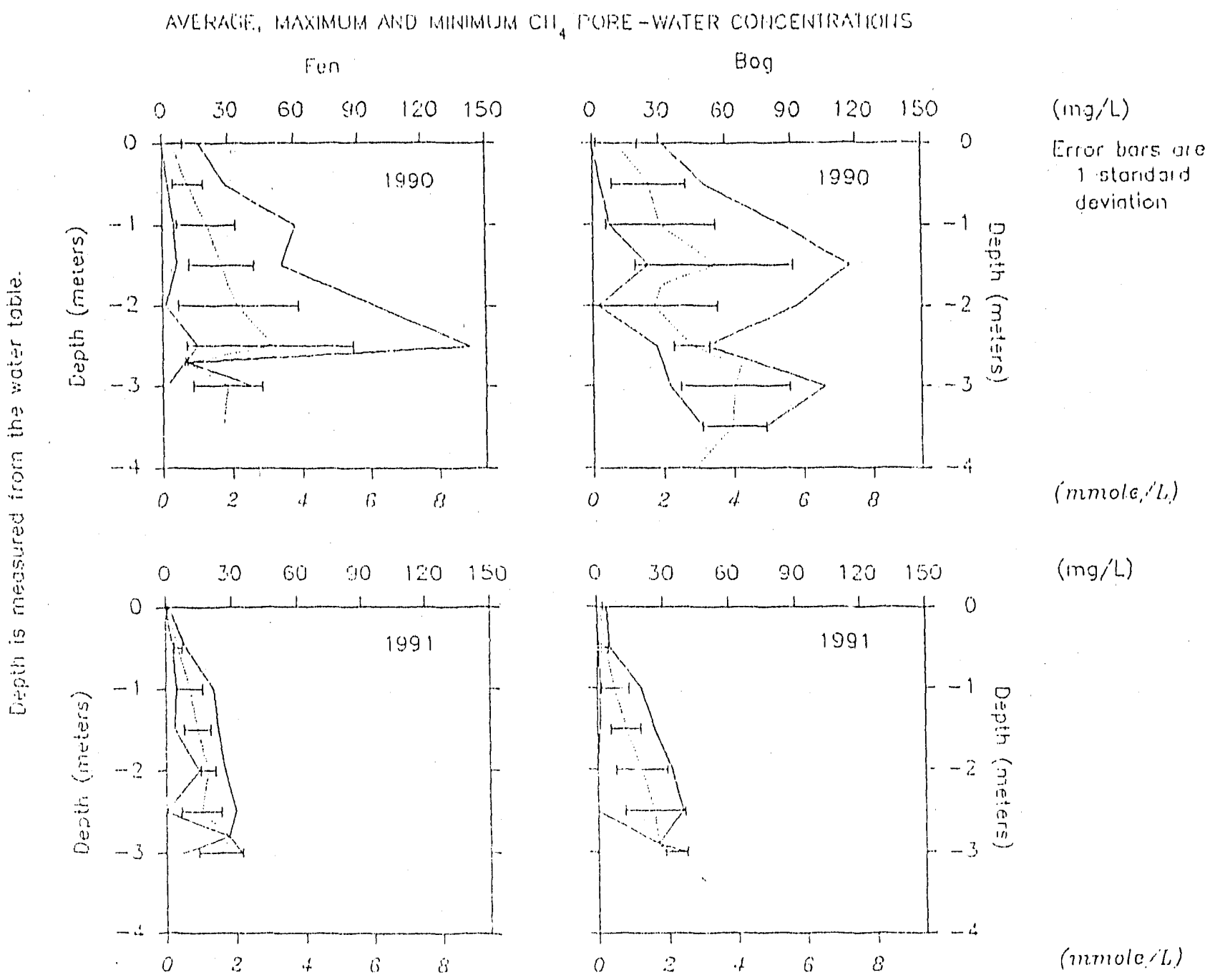

Figure 2. Statistical representation of methane profiles in the Glacial Lake Agassiz peatlands, sume 1990 and 1991. Wote the dramatic change in profiles between sampling times. 


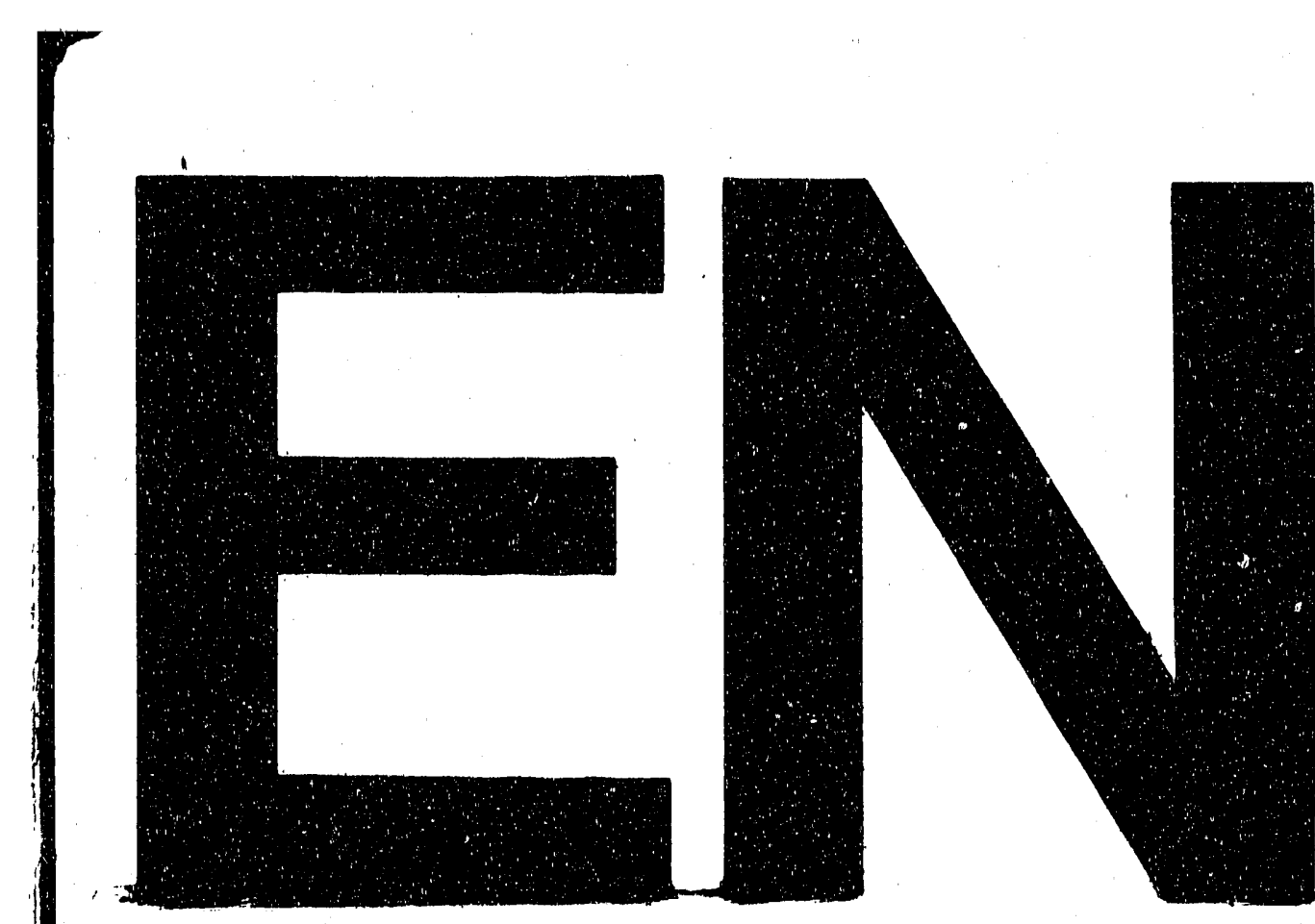




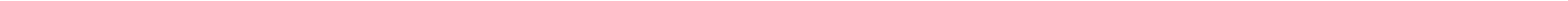

